\section{Effect of Local Application of Alendronate and Parathyroid Hormone on Craniofacial Bone Repair - a Preliminary Study}

Universidade Positivo,

Curitiba, PR, Brazil

Correspondence: Rafaela Scariot, Rua Prof. Pedro Viriato Parigot de Souza, 5300, 80740-050 Curitiba, PR, Brasil. Tel: +55-41-3317-3454. e-mail rafaela_scariot@yahoo.com.br
Frederico Ribeiro Deliberador, Aline Monise Sebastiani, Jennifer Gerber, Luana Bonetto, Gabriela Tórtora, Allan Fernando Giovanini, Tatiana Miranda Deliberador, Joao César Zielak, Rafaela Scariot

\begin{abstract}
This study aimed to evaluate the effect of two methods of local application of alendronate and parathyroid hormone (PTH) on bone repair and the systemic implications. A critically sized defect $(5 \mathrm{~mm})$ was created in the cranial region of twenty-five male Wistar rats, and the bone removed was particulated, and grafted back to the defect with different treatments. The animals were randomly divided into five groups: A1- bone graft immersion in alendronate solution $(3 \mathrm{mg} / \mathrm{kg}$ ) for 5 minutes; P1- bone graft immersion in PTH solution $(20 \mu \mathrm{g})$; A2- weekly local applications of alendronate $1 \mathrm{mg} / \mathrm{kg}$; P2- weekly local applications of PTH $(20 \mu \mathrm{g})$; C- no drugs were used. The animals were euthanized 60 days after surgery. Cranial bone blocks were removed for histological, histomorphometric, and immunohistochemical analyses. MMP-2 and MMP-9 were used for immunolabeling. The kidneys, liver, and brain were also removed from all the rats for histological analysis. The data were submitted for statistical analysis with a level of significance of 0.05 (One-way ANOVA). The group $\mathrm{C}$ and group P2 presented a higher quantity of viable bone particles than the remaining groups. Groups $A 1, A 2$, and $P 1$ presented with fewer viable bone particles than the control group, with a predominance of non-mineralized connective tissue. The histomorphometric analysis revealed no differences in relative bone area or MMP-2 or MMP-9 immunolabeling between the groups ( $p>0.05)$. Group A2 showed presence of fat in the liver consistent with hepatic steatosis. Changes in brain tissue were observed in groups $\mathrm{A} 1$ and $\mathrm{P} 1$.
\end{abstract}

Key Words: bone regeneration, bone resorption, osteogenesis, parathyroid hormone, alendronate.

\section{Introduction}

Bisphosphonates (BFs) are a class of drugs that are used to fight the effects of diseases affecting bone remodeling (1). They are the first-line drugs for treatment of osteoporosis (2) and are also used for treatment of other skeletal pathologies, such as multiple myeloma, bone pathologies associated with malignant neoplasia, and Paget's disease (3). Alendronate is a part of the second generation of the BFs class, and is the most widely used anti-resorptive drug (4).

Alendronate has been investigated as a therapeutic agent to improve bone formation in bone defect models $(5,6,7)$. It has been proven that BFs exert effects on the matrix metalloproteinases (MMPs), and the production of these proteins influences bone resorption. In 2008, Ichinose et al (8) found that, in presence of physiological concentrations of plasmin, bisphosphonates reduced the amount of MMP2 in osteoblast-conditioned media, suggesting that BFs inhibit bone resorption by abrogating MMP-2 protection induced by plasmin-mediated degradation. Another study (9) examining the effects of alendronate on growth of the condylar cartilage verified that the number of chondroclasts engaged in hypertrophied cartilage resorption was reduced significantly by alendronate treatment, at the same time reducing the expression of the level of MMP-9 at both the transcription and translation levels.

There are a few studies associating systemic application of alendronate, either intraperitoneally $(10,11)$ or subcutaneously (12) or by the topical route, either by irrigation (13) or by local application (7), with bone repair in cranial defects. Due to a certain similarity between alendronate and parathyroid hormone (PTH) with regard to the potential of accelerating bone replenishment, some authors have been working on comparing these drugs in the same study $(14,15)$. PTH is a protein hormone synthetized by the parathyroid gland (16) that acts as an osteogenic agent (2). When administered systemically, PTH induces bone formation by stimulating osteoblast proliferation, prevents osteoblast apoptosis, and increases osteoblast activity (2).

The systemic implications of the use of these drugs depend directly on the route of administration and the dose used. There is still scarce information in literature about this. It is previously known that alendronate alters bone metabolism and in some cases, may also produce enteric 
and gastric ulcerations (17). PTH acts directly on the bones and kidneys and indirectly on the intestines, increasing the flow of calcium into the bloodstream (18). However, the effects of its topical application are not yet clear (19).

It is of interest to determine which substances can accelerate and promote bone repair in bone grafts (20). The effectiveness, best route of administration, and systemic implications of BFs and PTH for craniofacial bone repair have not yet been determined. There are few studies evaluating the effect of local application of Alendronate or PTH directly on the grafted region. There is also only one study evaluating graft immersion in these drugs and the systematic implication of these administration routes in the animal. Based on these premises, the aim of the present study was to evaluate the effect of two methods of local application of alendronate and parathyroid hormone (PTH) on bone repair and to evaluate the systemic implications of these medications on the kidney, liver, and brain.

\section{Material and Methods}

An experimental study was performed on 25 male Wistar rats, 3 months of age, weighing 325-490 g each. The rats were randomly divided into five groups of five rats each. The

$$
\text { (2) }
$$

- light/dark photoperiod, temperature of $18-22^{\circ} \mathrm{C}$, and $65 \%$ humidity. Light, temperature, and humidity conditions in the rooms were controlled digitally.

\section{Surgical Procedure}

The rats were sedated by inhalation of isoflurane (Cristália, Itapira, SP, Brazil) for 1 min and then anesthetized with 10\% ketamine hydrochloride (Vetbrands, Paulínia, SP, Brazil) and 2\% xylazine hydrochloride (Vetbrands) by intraperitoneal injection. Following anesthesia, a trichotomy of the frontoparietal region was performed, followed by vigorous disinfection with iodopovidone. A semilunar posterior to anterior incision was then made in the cranial calotte using a no. 15 scalpel blade while fullthickness flaps were raised to widely expose the cortical bone using a Molt periosteal elevator.

A critically sized transosseous defect ( $5 \mathrm{~mm}$ in diameter) was created using a trephine (Neodent, Curitiba, PR, Brazil) mounted on an implant contra angle handpiece 20:1 (Kavo, Joinville, SC, Brazil) under abundant irrigation with $0.9 \%$ sterile saline solution. The removed bone was particulated through five beats in a bone grinder type pile (Kopp, Curitiba, PR, Brazil), which allows the creation of bone particles of different sizes. The particulated bone was grafted back into the defect region. During the surgical procedure, an L-shaped mark was made bilaterally on the defect, filled with amalgam, and used as a reference for serial longitudinal sections beginning at the center of the original surgical defect for histological analysis.

In group A1, after removal and particulation, the bone was immersed in sodium alendronate $3 \mathrm{mg} / \mathrm{kg}$ for $5 \mathrm{~min}$ and then grafted back into the original region. Group P1 received similar treatment but with immersion in $20 \mu \mathrm{g}$ of PTH (Forteo Colter Penâ, Eli Lilly and Company, São Paulo, SP, Brazil). Pure sodium alendronate was obtained from a handling pharmacy. For preparation of solution, a pilot study found that the final volume that could be applied to the animal without causing discomfort is 0.1 $\mathrm{mL}$ A solution was prepared with saline, in which $0.1 \mathrm{~mL}$ of the solution had $1 \mathrm{mg}$ of alendronate. For each animal, the final dose of the solution based on body mass was calculated individually. For preparation of the immersion solution, alendronate was already concentrated to $3 \mathrm{mg}$ in $0.1 \mathrm{~mL}$ of the solution. The amount of solution used for immersion of the graft corresponded to $3 \mathrm{~mL}$. For PTH, the solution was already ready in the pen, and each application would correspond to $20 \mu \mathrm{g}$. For immersion of the graft, the solution was allocated in a dappen pot. The dose of both alendronate and PTH preconized here was based on the weekly dose for the treatment of osteoporosis in humans

The rats in the remaining two groups, $\mathrm{A} 2$ and $\mathrm{P} 2$, received only the particulated graft. Postoperatively, group A2 received injections of sodium alendronate (1 $\mathrm{mg} / \mathrm{kg}$ ), while group P2 received injections of PTH (20 $\mu \mathrm{g})$. Application began on the day of defect creation and was performed weekly until euthanasia up to a total of eight applications. In groups A2 and P2, to standardize the application site, a mark was made before the incision using a 5-mg Pro Needles tattoo needle and tribal black ink (Electric Ink, Uberaba, MG, Brazil). Group C (control) received no drug treatment after the defect creation. It is important to note that the dose of alendronate was different for immersion and local application. This was because necrosis of the skin of the animal was observed in a pilot project when applied at a concentration of $3 \mathrm{mg} /$ $\mathrm{kg}$ in the region of the defect.

Postoperative analgesia consisted of paracetamol (1.5 $\mathrm{mg} / 100 \mathrm{~g}$ weight) dissolved in $400 \mathrm{~mL}$ of water placed in the drinking trough for 3 days. To avoid infection, 10 $\mathrm{mg} / \mathrm{kg}$ of enrofloxacin was administered intramuscularly following surgery (Pentabiótico Veterinário, FontouraWyeth, Guarulhos, SP, Brazil). The animals were evaluated daily for tissue healing.

\section{Euthanasia and Specimen Processing}

After 60 days, the rats were euthanized in a gas chamber $\left(\mathrm{CO}_{2}\right.$ for $\left.10 \mathrm{~min}\right)$. Bone blocks surrounding the cranial defect 
regions were removed for subsequent analysis. The kidneys, liver, and brain were also removed and preserved in 10\% formalin for subsequent histological analysis.

A time period of 60 days was established in order to verify the consequences of each hormone or drug used. It was previously known that the all drug or hormone analogues act in hormone system complex or intermediate metabolism. It has been highlighted that the important fraction of pre-hormones has been produced previously, and the real action of alendronate or PTH has been inferred to occur in later stages (21).

For histological processing, the bone blocks were decalcified in 7\% ethylenediaminetetraacetic acid for 45 days. Following demineralization, the specimens were hemi-sectioned parallel to the middle of the defect. The kidneys, liver, and brain were placed in formaldehyde following euthanasia and subsequently hemi-sectioned longitudinally. The specimens were processed and embedded in paraffin. Serial longitudinal $3-\mu m$-thick sections were cut beginning at the center of the original surgical defect. The specimens were stained with hematoxylin and eosin.

For histochemical processing, the $3-\mu m$-thick serial sections were deparaffinized and subjected to antigen retrieval in $1 \mathrm{~N}$ trypsin ( $\mathrm{pH} 7.2$ ) for $60 \mathrm{~min}$ at $37^{\circ} \mathrm{C}$. Slides with histological sections were immersed in hydrogen peroxidase for $30 \mathrm{~min}$ to inactivate the endogenous peroxidases and incubated in 1\% sodium phosphate ( $\mathrm{pH}$ 7.4). The sections were incubated with the primary antibodies anti-MMP-2 (NCL-MMP-2-507 mouse monoclonal; Novocastra ${ }^{\circledR}$, Leica Biosystems, Newcastle Ltd, UK) and anti-MMP-9 (NCLMMP-9-439 mouse monoclonal 23; Novocastra ${ }^{\circledR}$, Leica Biosystems), both at 1:20 dilution for $18 \mathrm{~h}$, followed by incubation with secondary antibody solution (Advance ${ }^{\mathrm{TM}}$ HRP Label Link and Enzyme K4068; Dako ${ }^{\circledR}$, Glostrup, Germany) to detect the primary antibodies. We chose MMP-2 and MMP-9 since they are gelatinases involved in loss of calcium and reabsorption of bone tissue (22).

The reactions were developed with 3'3 diaminobenzidine tetrachloride (Sigma, St Louis, MO, USA) for 3 min, resulting in a brownish color at the site of the antigen-antibody reaction. The sections were counterstained with Harris hematoxylin. Three sections were used for each specimen and incubation with each antibody.

\section{Histological Analysis}

Two histological sections were selected for each animal, representing the center of the original surgical defect. All analyses were performed by a single operator. For qualitative histological analysis, the image analysis was performed using a light microscope (021/3 Quimis; Diadema, SP, Brazil). The following parameters were evaluated: bone deposition, graft particles with viable bone cells, graft particles undergoing osseointegration, and connective tissue characteristics.

Histological analyses of the kidneys, liver, and brain were performed using hematoxylin and eosin staining. The obtained sections were compared to normal standards established in the literature.

\section{Histomorphometric Analysis}

For the histomorphometric analysis, all the slides containing sections of the defect were photographed in succession using a digital camera (EOS Rebel T5; Canon, Tokyo, Japan) coupled with a microscope (OBX41; Olympus, Melville, NY, USA) at $40 \times$ magnification and an image of the whole defect was taken, grouped, and treated using Microsoft PowerPoint ${ }^{\circledR}$ (Microsoft Corporation, Redmond, WA, USA) to form a single continuous image comprising the two borders of the defect. Three serial slices of the same specimen were obtained and all of them were used for data collection. The following histomorphometric measurements were performed using Image J software:

1. Bone area: measured for bone tissue areas in $\mathrm{mm}^{2}$.

2. Histological defect area: total area of the surgically created defect: measured from border to border of the original defect, including calotte thickness variation for each animal in $\mathrm{mm}^{2}$.

3. Relative bone area (\%): percentage area of bone tissue relative to the histological defect area calculated using the rule of three.

The relative bone area undergoing osseointegration was subsequently calculated as the ratio between the percentages of slides showing osseointegration and the relative bone area.

\section{Immunohistochemical Analysis}

For immunohistochemical analysis, using the same slides, a series of five photos was taken per slide, distributed between the borders of the bone defect using a digital camera (EOS Rebel T5; Canon), coupled with a microscope (BX41; Olympus) at $400 \times$ magnification. The images were treated using Image J software. Following treatment, the intensity of immunolabeling for the two metalloproteinases was measured. The values imported from Image $J$ are the image pixels multiplied by $10^{6} \mathrm{in} \mathrm{mm}^{2}$.

\section{Statistical Analysis}

The data were subjected to descriptive and statistical analyses. For parametric numerical variables, one-way analysis of variance, followed by Tukey's test, was used to test for significant differences between treatments $(p<$ 0.05). Statistical analyses were performed using Statistical Package for Social Science ${ }^{\circledast}$ software (SPSS version 24.0; SPSS Inc., Chicago, IL, USA) at a 95\% confidence interval. 


\section{Results}

\section{Histological Evaluation}

On the $60^{\text {th }}$ day of analysis all groups evaluated, demonstrated similar histological pattern. Bone graft particles presenting basophilic reversal lines on their peripheral face indicating osteoconduction properties were seen. Each one of these fragment bones were surrounded by preeminent fibrous connective tissue that exhibited scarce fusiform cellularity. Despite these similarities, the amount of new bone formation adjacent to the particles, as well as the bone matrix that compounded all defects was different, and these differences may be seen in Figure 1 .

Regarding the systemic effects of the drugs tested, all groups presented normal-appearing kidneys (Fig. 2A-2E). Normal glomeruli were observed, surrounded by capillaries and patent collecting ducts.

Groups $\mathrm{C}, \mathrm{A} 1, \mathrm{P} 1$, and $\mathrm{P} 2$ also presented normal-looking livers with usual characteristics and numerous apparent sinusoidal capillaries between the hepatocyte plates (Fig. $3 \mathrm{~A}-3 \mathrm{E})$. However, group A2 showed the presence of liver fat, consistent with hepatic steatosis (Fig. 3D).

Histological analysis revealed normal-looking brains in group C (Fig. 4A), with the cerebral cortex demonstrating normal characteristics including numerous neurons, a normal amount of white matter, presence of basal nuclei, and normal ventricles. Groups A2 and P2 also demonstrated normal-looking brains similar to those in the control group (Fig. 4C, 4D). Group A1 however, showed loss of brain tissue structures consistent with necrosis, with many oligodendrocytes phagocytizing the area (Fig. 4B). Group $\mathrm{P} 1$, which received treatment consisting of PTH immersion, presented dystrophic calcification inside the ventricle (Fig. $4 \mathrm{E}, 4 \mathrm{~F})$. Loss of matter was also observed in the borders of the brain tissue next to the areas of dystrophic calcification.
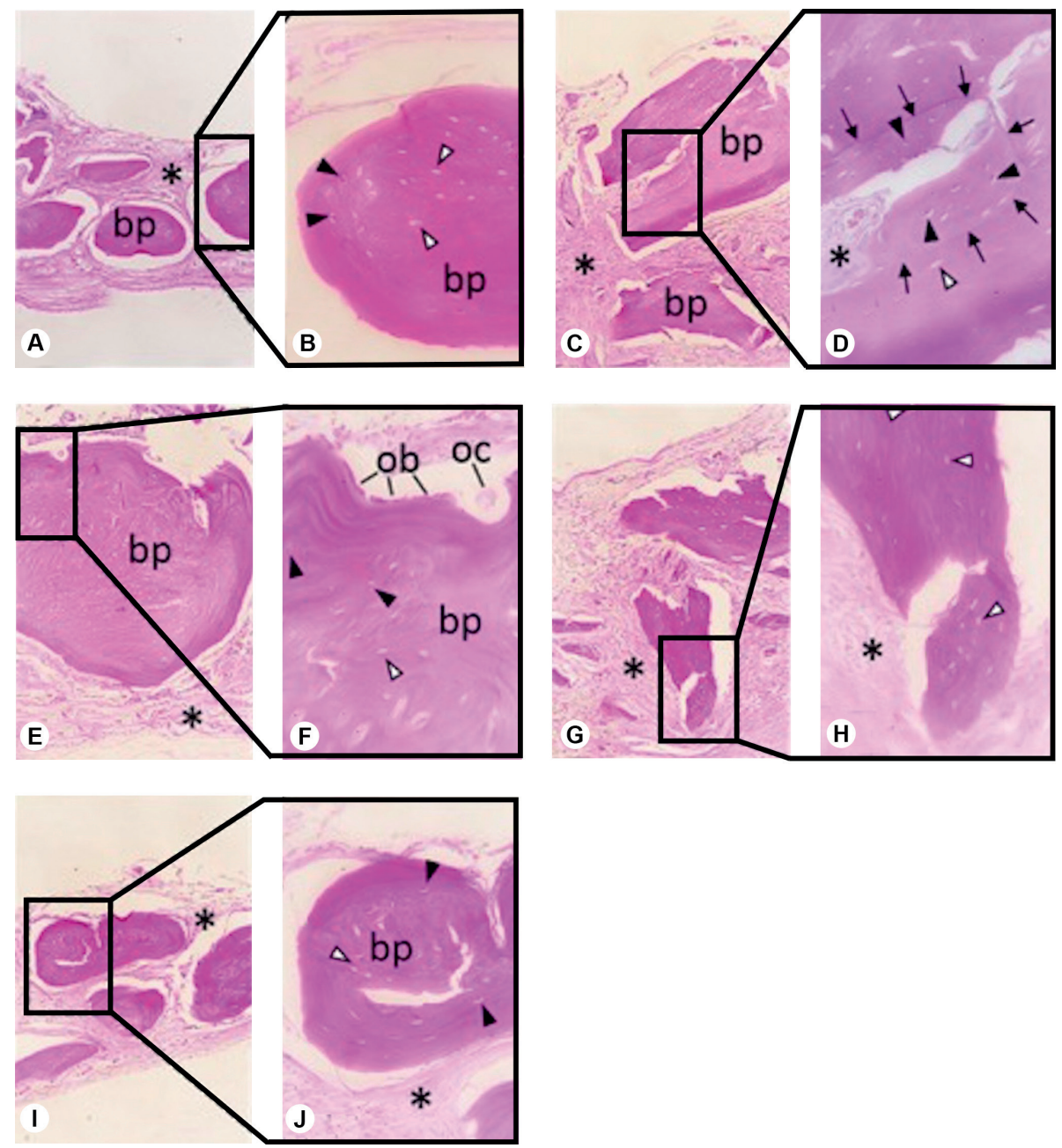

Figure 1. Histological images of the critically sized defect in the five different experimental groups (hematoxylin and eosin staining). A) Control group (100x). B) Control group (400x). C) Group A1 (100x). D) Group A1 (400x). E) Group A2 (100x). F) Group A2 (400x). G) Group P1 (100x). H) Group P1 (400x). I) Group P2 (100x). J) Group P2 (400x). bp, bone particle; *, connective tissue; black triangle, viable osteocytes with nuclei; white triangle, osteocyte empty gaps; black arrow, bone neoformation; ob, osteoblasts; oc, osteoclasts. 


\section{Histomorphometric Analysis}

The average histological defect area, bone area, relative bone area, and relative bone area undergoing osseointegration for all groups are shown in Table 1. No statistically significant differences were observed between groups for any of the parameters ( $p>0.05$ ).

The relative bone area undergoing osseointegration was $21.23 \%$ for the control group, $8.89 \%$ for group $\mathrm{A} 1$, $10.64 \%$ for group A2, $14.11 \%$ for group P1, and $18.65 \%$ for group P2.

\section{Immunohistochemical Analysis}

For the control group, homogeneous immunolabeling was observed in the connective tissue matrix for both MMP-2 and MMP-9, showing the absence of graft particles, presence of typical cells and connective tissue, and local neovascularization (Fig.5A, 6A).

For MMP-2, in group $\mathrm{A} 1$, where the graft particles remained in the defect, labeling was slightly concentrated in the borders of the graft particles (Fig. 5B). Group A2 presented a lower bone particle resorption rate, closer to the control group, and a predominance of densely organized connective tissue, also homogeneously labeled (Fig. 5C). Group P1 also presented with homogeneous immunolabeling of the connective tissue with presence of neovascularization (Fig.5D). Group P2 presented with connective tissue matrix labeling similar to the remaining groups, but active osteocytes were observed within the borders of graft particles at 400x magnification (Fig. 5E).

For MMP-9, overall homogeneous immunolabeling was observed. The control group presented with connective tissue that was more reticulated and neovascularized with few autogenous bone particles (Fig. 6A). Group A1 also demonstrated slightly more intense immunolabeling around the autogenous bone (Fig. 6B). Group A2 showed light immunolabeling and dense and organized connective tissue (Fig. 6C). In group P1, the immunolabeling was concentrated around the bone graft particles (Fig. 6D). Group P2 showed live osteocytes on the periphery of autogenous bone graft particles with immunolabeling concentrated in the focal
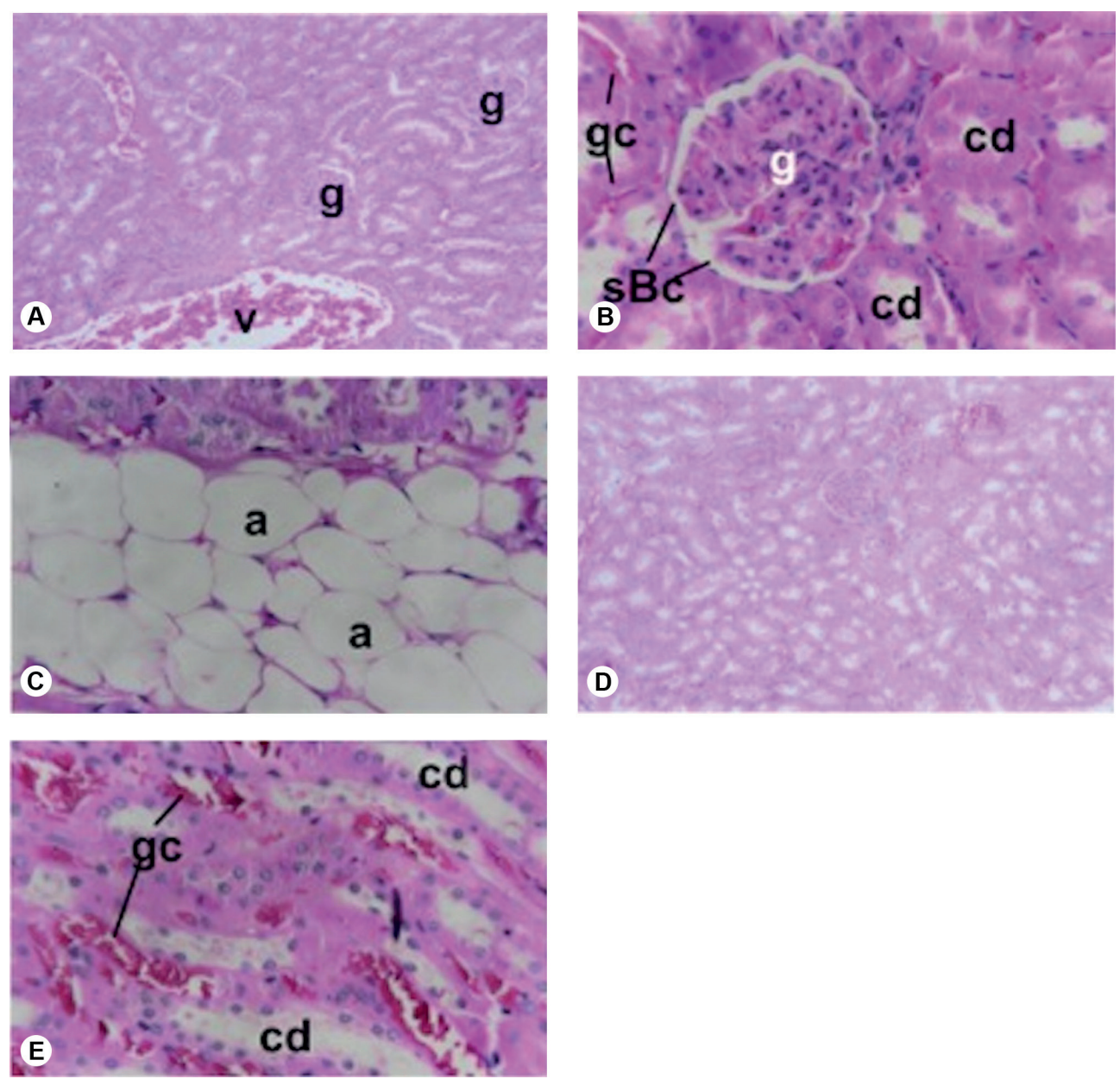

Figure 2. Histological images of the kidney in the different experimental groups, stained with hematoxylin and eosin. A) Control group (100x). B) Group A1 (400x). C) Group A2 (400x). D) Group P2 (100x). G, glomerulus; v, vein; gc, glomerular capillaries; a, adipocytes; cd, collecting duct; sBc, Bowman's space. 
points within the connective tissue matrix permeated by homogeneously separated cells (Fig. 6E).

The average immunolabeling intensities for the different groups are presented in Table 2. No statistically significant differences in immunolabeling intensity were observed between the groups for both MMP-2 and MMP-9 ( $p>0.05)$.

\section{Discussion}

There has been great interest in identifying a way to induce bone regeneration or neoformation (23). BFs and PTH have been suggested for bone regeneration within the craniofacial structures $(5,24,25)$. However, the best route of administration for these drugs to accelerate bone repair has not been determined. Sodium alendronate and PTH can be administered via the same systemic or local routes $(7,10-13,18,19)$. Systemic administration of these drugs, either orally or by injection, may not be easily accepted by the patients being subjected to bone grafting procedures. In addition, they may cause undesirable systemic effects
$(26,27)$. Therefore, the present preliminary study was designed to test two methods of local application of alendronate and PTH that are considered feasible in clinical practice: local injection into the graft area and graft immersion prior to grafting.

The local application of BFs appears to accelerate bone repair in fractures (28) and grafted areas (6). Agholme and Aspenberg (29) reported that soaking bone grafts in alendronate solution ( $2 \mathrm{mg} / \mathrm{mL}$ diluted in saline) before implantation can prevent their resorption and increase local bone density in rats and humans. Ozer et al. in 2017 (30) also founded that the residual graft area 4 and 8 weeks postoperatively, was significantly higher when associated with alendronate irrigation during autogenous bone grafting in mandibular circular defects. This finding is in contrast with that of the present study, in which the histological analysis revealed that group $A 1$, which consisted of treatment with graft immersion in alendronate solution, presented lower bone relative area and fewer
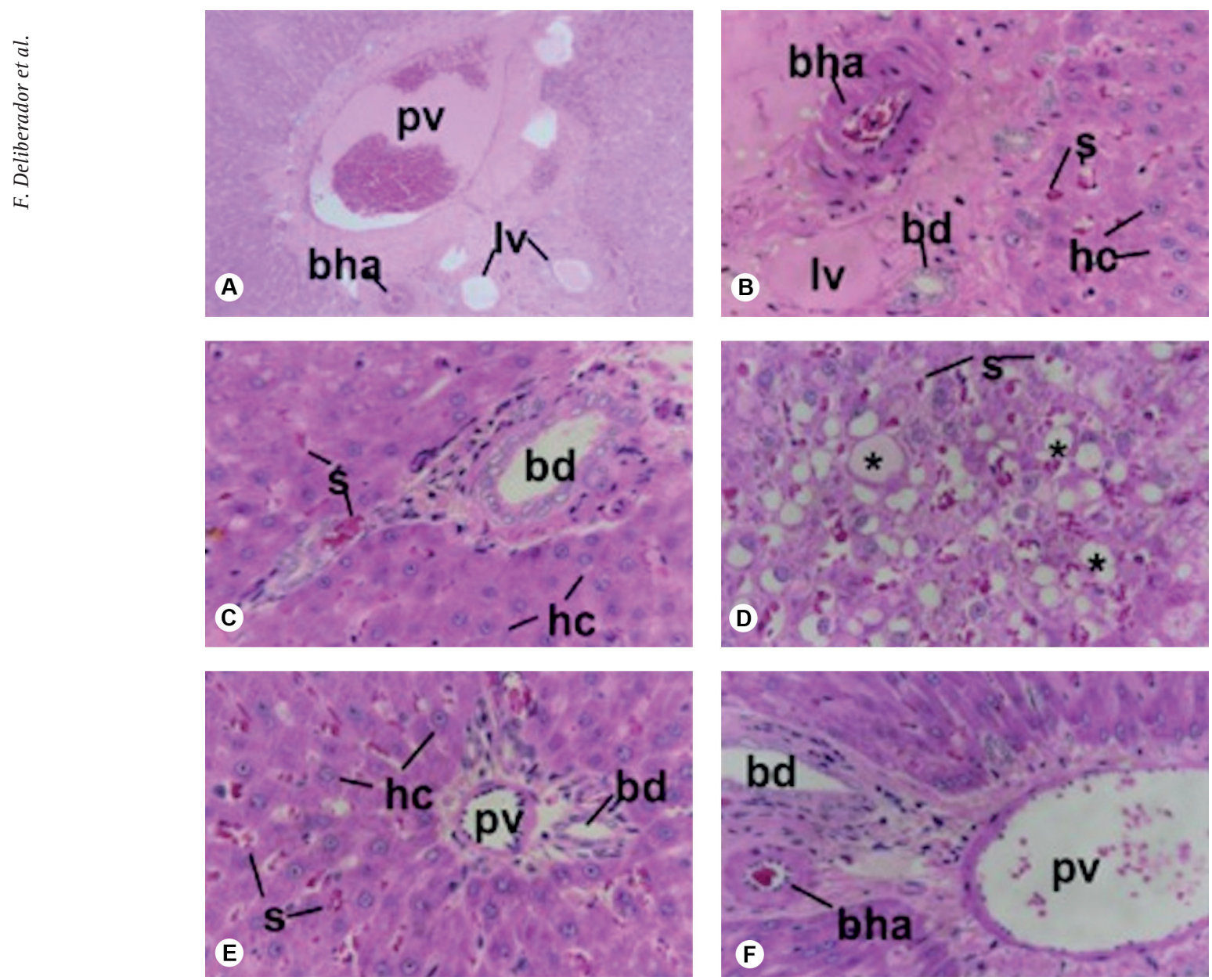

Figure 3. Histological images of the liver in the different experimental groups stained with hematoxylin and eosin. A) Control group (100x). B) Control group (400x). C) Group A1 (400x). D) Group A2 (400x). E) Group P1 (400x). F) Group P2 (400x). Pv, portal vein; bd, biliary duct; bha, hepatic artery branch; lv, lymphatic vessel; s, capillary sinusoids; *, hepatic steatosis; hc, hepatocytes. 
particles undergoing osseointegration than the control group. A tendency for osseointegration in the more internal particle surfaces, which the drug may not have reached, was also observed. In addition, group A1 presented the lowest relative bone area. In our study, the results with regard to local application of alendronate, that is, in group A2, were similar to those in the control group. In fact, literature shows that single use of alendronate by the local application approach did not contribute to bone repair significantly (31-34). On the other hand, bisphosphonates are proven to be effective in inhibiting bone loss due to their ability of decreasing osteoclastic activity, but are not effective in improving bone density in the bone formation phase (35). Some authors, to further promote bone healing, have combined bisphosphonates with other substances, such as collagen membrane and different graft materials, achieving

Table 1. Histological defect area and bone area, in $\mathrm{mm}^{2}$, and percentage of newly formed bone for each experimental group. Values are presented as mean \pm standard deviation (SD).

\begin{tabular}{lccccc}
\hline & Group c & Group A1 & Group A2 & Group P1 & Group P2 \\
\hline HA (Mean + sd) & $0.11 \pm 0.03$ & $0.33 \pm 0.33$ & $0.15 \pm 0.06$ & $0.17 \pm 0.03$ & $0.16 \pm 0.01$ \\
BA (Mean + sd) & $0.03 \pm 0.18$ & $0.05 \pm 0.01$ & $0.04 \pm 0.02$ & $0.06 \pm 0.05$ & $0.05 \pm 0.03$ \\
RBA (\%) & 26.54 & 14.83 & 26.60 & 35.29 & 31.25 \\
\hline
\end{tabular}

HA: histological defect area; BA: bone area; RBA: relative bone area. One-way ( $>0.05$ )
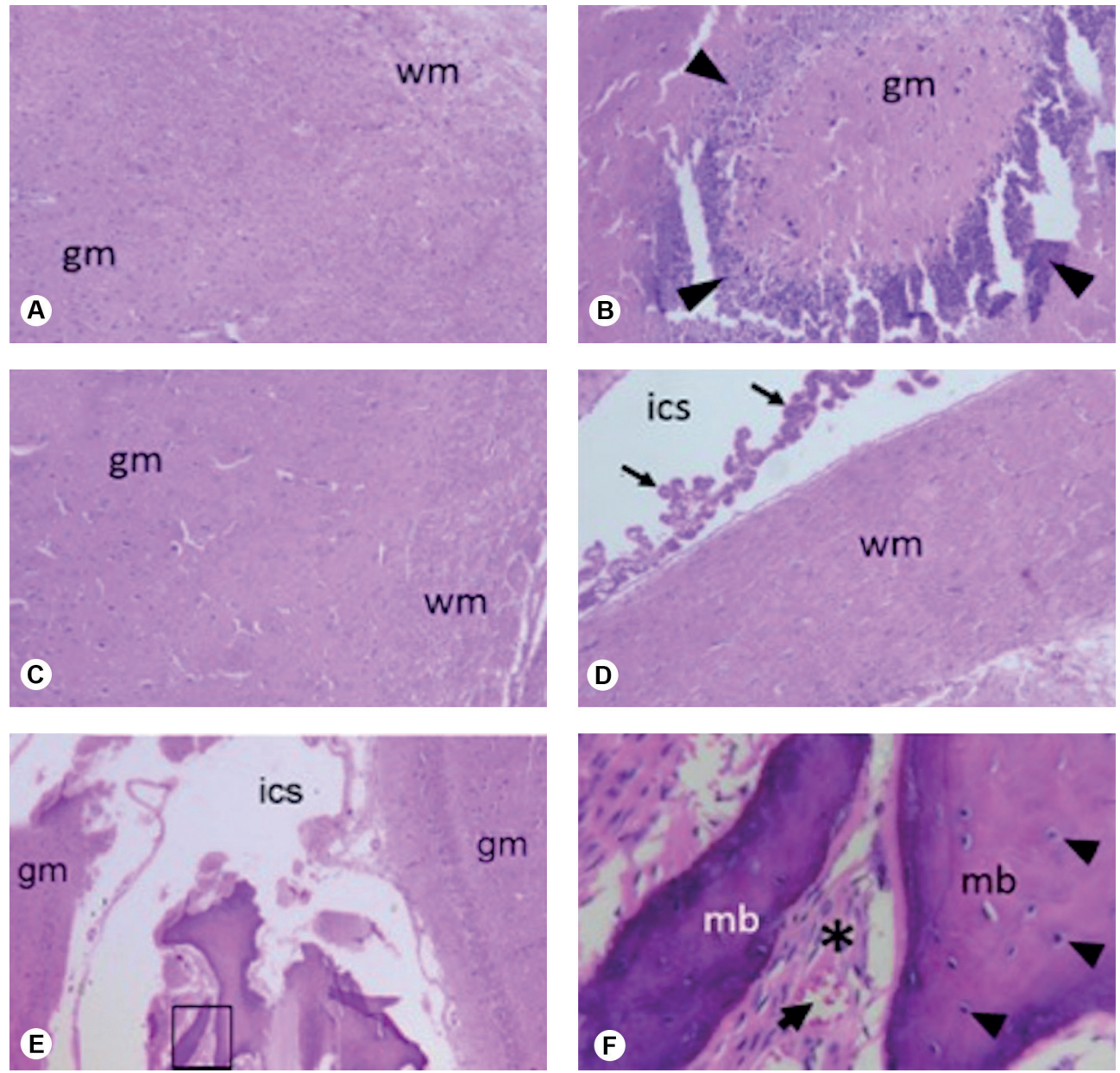

Figure 4. Histological images of the brain from the different experimental groups. A) Control group (100x). B) Group A1 (100x). C) Group A2 (100x). D) Group P2 (100x) E) Group P1 (40x). F) Group P1 (400x). ics, intercerebral space; wm, white matter; gm, gray matter; (arrow), ependymal cord; (triangle), concentration of cells similar to oligodendrocytes indicating an area of nerve tissue degeneration; mb, mature bone; *, typical connective tissue; (arrow), blood vessel; (triangle), osteocyte. 
better bone repair outcomes $(30,36)$.

PTH acts by stimulating osteogenesis (2), and is considered the only therapeutic agent recommended for bone formation (37). Yun et al. (38) compared the effects of systemic administration of PTH $(15 \mu \mathrm{g} / \mathrm{kg} /$ day subcutaneously) and implantation of bone biomaterial, alone or in combination, on local bone formation, following the creation of critically sized calvarial defects in rats and found higher bone formation in the group that was systemically administered PTH. There are only two studies, evaluating local application of PTH for bone repair (19). Tokunaga et al. in 2011 (19) evaluated the effect of PTH topically injected into the buccal gingiva after inducing experimental periodontitis in rats and found greater bone recovery and increased osteoid formation on the surface of the alveolar bone in PTH-treated rats. In the present study, although no statistically significant differences were observed, a quantitative analysis of bone formation showed a higher relative bone area for the groups treated with PTH than for the control group for both local methods. PTH groups showed the best results when compared to the $A 1$ and A2 groups. Additionally, P2 demonstrated similarities to the control group in the histological assessment (several bone particles undergoing osseointegration, higher bone formation area and homogeneous MMP-2 and MMP-9 labeling in the extracellular matrix). Perhaps, PTH was not effective in accelerating bone repair in our trial, but our results show slight evidence of induction of bone formation, when compared with the control group. Further studies with larger samples are needed to better understand these results. Besides, it is known that regions where morphology and dimensions of the defects are extensive and critical, bone repair mechanisms are limited. Finally, it is important to note that bone healing experiments have been performed in rodent models, and the remodeling process in these animals is not similar to that in humans.

MMP-2 and MMP-9 expressions were also studied here with the hope that it would help elucidate potential differential responses in the designed interventions. The different expression patterns were intriguing despite all
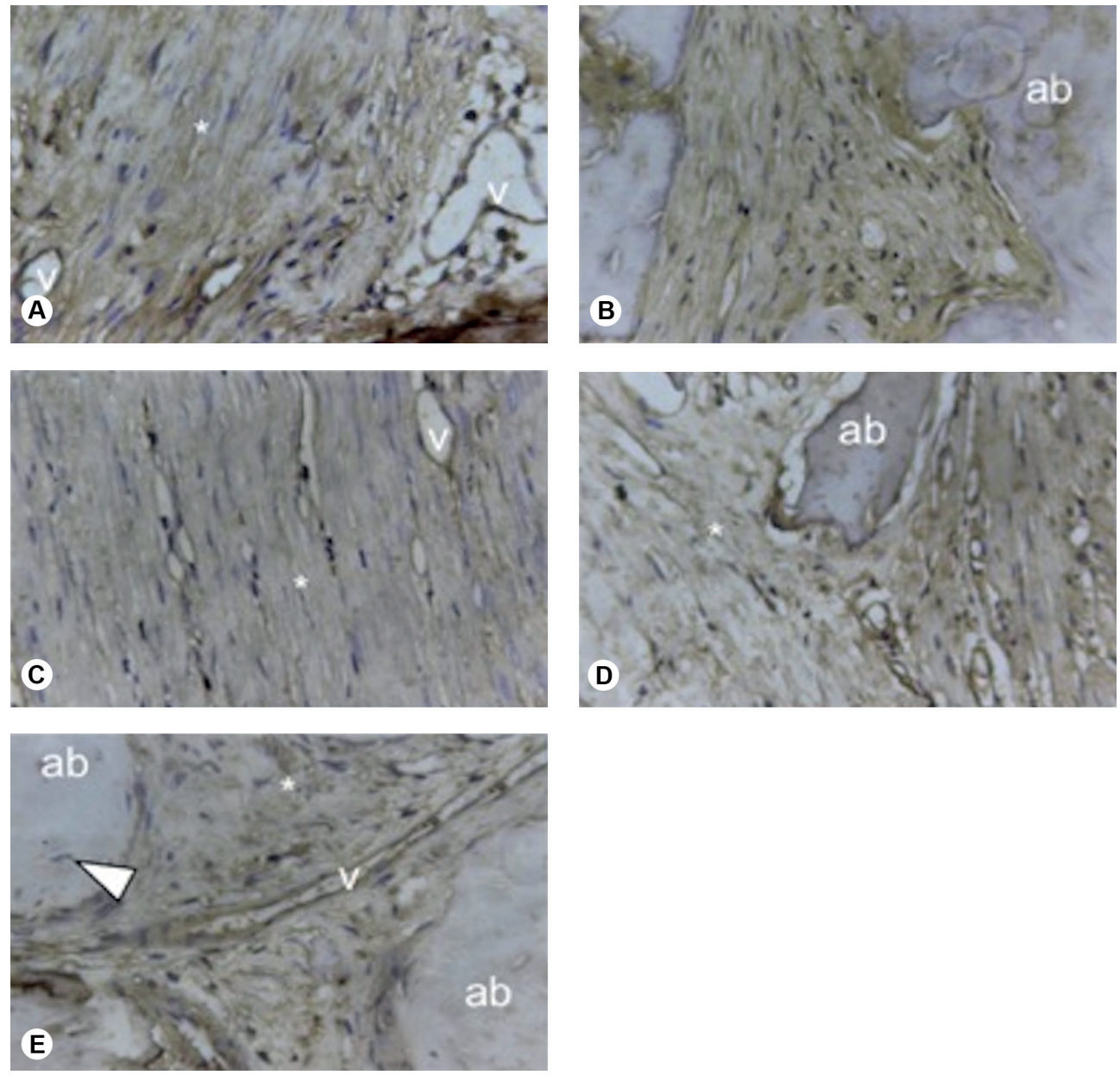

Figure 5: Immunohistochemical images for MMP-2 in the calotte defect region (original 400x). A) Control group. B) Group A1. C) Group A2. D) Group P1. E) Group P2. ab, autogenous bone particle; v, vessels; *, connective tissue; (arrow), osteocyte. 
groups expressing these two proteins. These differences may be due to different distributions of the medications when one immerses a specimen in a solution for 5 min versus targeted injections. Ultimately, diffusion of the drugs in connective tissue differs, which affects the MMP-2 and MMP-9 expression patterns.

Finally, our findings do not support the initial suggestion that BFs and PTH can induce and/or accelerate bone formation. Furthermore, the protocol for medication exposure we designed (i.e. immersion in solution for $5 \mathrm{~min}$ or local injections in the affected area) had systemic effects detected in the liver and brain but no negative effects on the kidneys such as nephrocalcinosis, gastrointestinal disorders (39) or the expected effect on bone formation (29). This is intriguing and possibly related to several factors such as the surgical defect size created or the specific resulting exposure to BFs and PTH allowed in our protocol.

In conclusion, the specific way BFs and PTH were used herein our study, and their effect on accelerating bone regeneration is not promising. However, our study identified a potential systemic effect of the administration of these drugs that ultimately may prevent widespread utilization of these approaches for bone regeneration. Therefore, it may be wise to start considering other ways

Table 2. Intensity of immunolabeling of MMP-2 and MMP-9 for all experimental groups (pixels 106). Values are presented as mean \pm standard deviation (SD).

\begin{tabular}{cccccc}
\hline & Group C & Group A1 & Group A2 & Group P1 & Group P2 \\
\hline MMP-2 & $6.084 \pm 0.840$ & $6.908 \pm 0.459$ & $6.674 \pm 1.392$ & $6.674 \pm 1.123$ & $6.167 \pm 0.854$ \\
MMP-9 & $7.378 \pm 0.780$ & $7.185 \pm 0.654$ & $6.498 \pm 0.696$ & $6.981 \pm 0.699$ & $6.528 \pm 0.741$ \\
\hline
\end{tabular}

One-way ANOVA ( $>0.05)$
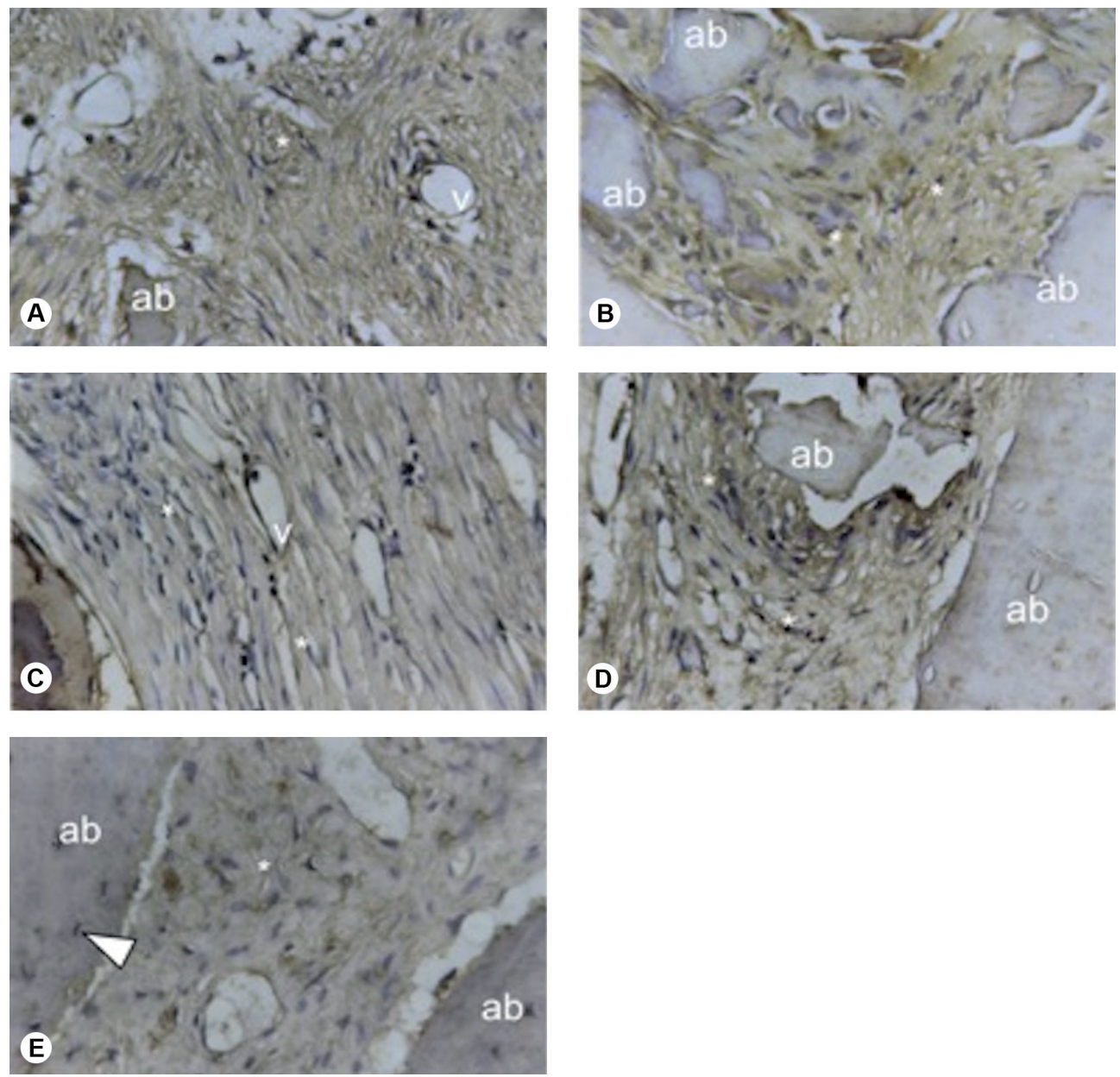

Figure 6: Histological images of critically sized calotte defects (400x) immunolabelled for MMP-9. A) Control group. B) Group A1. C) Group A2. D) Group P1. E) Group P2. ab, autogenous bone particle; v, vessels; *, connective tissue; (arrow), osteocyte. 
to achieve accelerated bone formation that can impact clinical management and provide new lines of treatment for acquired (traumatic) or congenital bone defects.

\section{Resumo}

Este estudo visou avaliar o efeito de dois métodos de aplicação local de alendronato e de paratormônio (PTH) no reparo ósseo e avaliar as implicações sistêmicas. Um defeito de tamanho crítico $(5 \mathrm{~mm})$ foi criado na calota craniana de vinte e cinco ratos Wistar machos, e o osso removido foi particulado e enxertado de volta no defeito com diferentes tratamentos. Os animais foram divididos aleatoriamente em cinco grupos: A1: imersão do enxerto ósseo em solução de alendronato $(3 \mathrm{mg} / \mathrm{kg})$ durante $5 \mathrm{~min}$; P1- imersão do osso em solução de PTH $(20 \mu \mathrm{g})$; A2- aplicações locais semanais de alendronato $1 \mathrm{mg} / \mathrm{kg}$; P2- aplicações locais semanais de PTH $20 \mu \mathrm{g}$; C: não foram utilizados medicamentos. Os animais foram eutanasiados 60 dias após a cirurgia. Foram removidos os blocos ósseos envolvendo a região do defeito para realização das análises histológica, histomorfométrica e imuno-histoquímica. MMP2 e MMP9 foram as imunomarcações utilizadas. Os rins, fígado e cérebro também foram removidos de todos os ratos para análise histológica. Os dados foram submetidos à análise estatística com um nível de significância de 0,05 (One-way ANOVA). A análise histológica revelou que o grupo $C$ e o grupo $\mathrm{P} 2$ apresentaram maior quantidade de partículas ósseas viáveis do que as apresentadas pelos demais grupos. Os grupos A1, A2 e P1 apresentaram menos partículas ósseas viáveis em comparação com o grupo controle com predominância de tecido conjuntivo não mineralizado. A análise histomorfométrica não revelou diferenças entres os grupos na área óssea relativa ou em MMP2 e MMP9 $(p>0,05)$. 0 grupo A2 mostrou presença de gordura no fígado consistente com esteatose hepática. Alterações no tecido cerebral foram observadas nos grupos A1 e P1.

\section{References}

1. Russell RG, Watts NB, Ebetino FH, Rogers MJ. Mechanisms of action of bisphosphonates: similarities and differences and their potential influence on clinical efficacy. Osteoporos Int 2008;19:733-759.

2. Iwata $A$, Kanayama $M$, Oha $F_{1}$ Hashimoto $T$, Iwasaki $N$. Effect of teriparatide (rh-PTH 1-34) versus bisphosphonate on the healing of osteoporotic vertebral compression fracture: A retrospective comparative study. BMC Musculoskelet Disord 2017;18:148.

3. Chaudhry AN, Ruggiero SL. Osteonecrosis and bisphosphonates in Oral and Maxillofacial Surgery. Oral Maxillofacial Surg Clin N Am 2007;19:199-206.

4. Maeda SS, Lazaretti-Castro M. An overview on the treatment of postmenopausal osteoporosis. Arq Bras Endocrinol Metabol 2014;58:162-71.

5. Koparal M, Gülsün B, Deveci E, Agacayak KS, Hamidi A. Effect of zoledronic acid application on different graft materials in calvarial bone defect models. An experimental analysis. Anal Quant Cytopathol Histpathol 2016;38:117-125.

6. Toker $\mathrm{H}, \mathrm{Ozdemir} \mathrm{H}, \mathrm{Ozer} \mathrm{H}$, Eren K. Alendronate enhances osseous healing in a rat calvarial defect model. Arch Oral Biol 2012;57:1545550.

7. Toker $\mathrm{H}$, Ozdemir $\mathrm{H}$, Ozer $\mathrm{H}$, Eren $\mathrm{K}$. A comparative evaluation of the systemic and local alendronate treatment in synthetic bone graft: a histologic and histomorphometric study in a rat calvarial defect model. Oral Surg Oral Med Oral Pathol Oral Radiol 2012;114(5 Suppl):S146-52.

8. Ichinose Y, Migita K, Nakashima T, Kawakami A, Aoyagi T, Eguchi K. Effects of bisphosphonate on the release of MMP-2 from cultured human osteoblasts. Tohoku J Exp Med 2000;192:111-118.

9. Kim MS, Jung SY, Kang JH, Kim HJ, Ko HM, Jung JY, et al. Effects of bisphosphonate on the endochondral bone formation of the mandibular condyle. Anat Histol Embryol 2009;38:321-326.

10. Giovanini AF, de Sousa Passoni GN, Göhringer I, Deliberador TM, Zielak $J C$, Storrer CLM, et al. Prolonged use of alendronate alters the biology of cranial repair in estrogen deficient rats' associated simultaneous immunohistochemical expression of TGF- $\beta 1+, \alpha-E R+$, and BMPR1B.
Clin Oral Investig 2018;22:1959-1971.

11. Vieira JS, Giovanini A, Görhinger I, Gonzaga CC, Costa-Casagrande TA, Deliberador TM, et al. Use of low-dose alendronate improves cranial bone repair and is associated with an increase of osteocalcin: An experimental study. J Oral Maxillofac Surg 2017;75:1873-1881.

12. Camati PR, Giovanini AF, de Miranda Peixoto HE, Schuanka CM, Giacomel MC, de Araújo MR, et al. Immunoexpression of IGF1, IGF2, and osteopontin in craniofacial bone repair associated with autogenous grafting in rat models treated with alendronate sodium. Clin Oral Investig 2017;21:1895-1903.

13. Özer T, Akta A, Barı E, Çelik HH, Vatansever A. Effects of local alendronate administration on bone defect healing. Histomorphometric and radiological evaluation in a rabbit model. Acta Cir Bras 2017;32:781795.

14. Kuroshima S, Entezami P, McCauley LK, Yamashita J. Early effects of parathyroid hormone on bisphosphonate/steroid-associated compromised osseous wound healing. Osteoporos Int 2014;25:11411150.

15. Altman AR, de Bakker CM, Tseng WJ, Chandra A, Qin L, Liu XS. Enhanced individual trabecular repair and its mechanical implications in parathyroid hormone and alendronate treated rat tibial bone. J Biomech Eng 2015;137.

16. Zeng $X, H e ~ H, Z$ Zhang $L, W u Y$, Wang $Y$, Gong P. A potential therapeutic approach to overload-induced bone loss around implant: Parathyroid hormone (PTH). Med Hypotheses 2011;77:701-704.

17. Graham DY1, Malaty HM. Alendronate gastric ulcers. Aliment Pharmacol Ther 1999;13:515-519.

18. Gracitelli MEC, Vidoris AAC, Luba $R$, Lazaretti-Castro M. Parathyroid hormone and osteoporosis: solving the puzzle. Physiologic rationale for the therapeutic use of PTH in osteoporosis. Arq Bras Endocrinol Metab 2002;46:215-220.

19. Tokunaga $\mathrm{K}$, Seto $\mathrm{H}$, Ohba $\mathrm{H}$. Topical and intermittent application of parathyroid hormone recovers alveolar bone loss in rat experimental periodontitis. J Periodont Res 2011;46:655-662.

20. Sheikh Z, Hamdan N, Ikeda Y, Grynpas M, Ganss B, Glogauer M. Natural graft tissues and synthetic biomaterials for periodontal and alveolar bone reconstructive applications: a review. Biomater Res 2017 [Epub ahead of print. doi: 10.1186/s40824-017-0095-5].

21. Harrison $T R$, Petersdorf $R G$, Adams RD, Braunwald $E$, Isselbacher $K J$, Martin JB, et al. Medicina interna. Rio de Janeiro: Guanabara Koogan $1984 ; 1$.

22. Nyman JS, Lynch CC, Perrien DS, Thiolloy S, O'Quinn EC, Patil CA, et al. Differential effects between the loss of MMP-2 and MMP-9 on structural and tissue-level properties of bone. J Bone Miner Res 2011;26:1252-1260.

23. Wang J, Li J, Yang L, Zhou Y, Wang Y. Dose-dependence of PTH-related peptide-1 on the osteogenic induction of MC3T3-E1 cells in vitro. Medicine 2017;96:e6637.

24. Clarke B. Normal bone anatomy and physiology. Clin J Am Soc Nephrol 2008;3:S131-S139

25. Takeuchi Y. Innovation of bisphosphonates for improvement of adherence. Clin Calcium 2017;27:197-202.

26. Neer R, Arnaud CD, Zanchetta JR, Prince R, Gaich GA, Reginster JY, et al. Effect of parathytoid hormone (1-34) on fractures and bone mineral density in postmenopausal women with osteoporosis. N Engl J Med 2001;344:1434-1441.

27. Vidal-Real C, Pérez-Sayáns M, Suárez-Peñaranda JM, Gándara-Rey JM, Garcia-Garcia A, et al. Osteonecrosis of the jaws in 194 patients who have undergone intravenous bisphosphonate therapy in Spain. Med Oral Patol Oral Cir Bucal 2015;20:e267-e272.

28. Greiner SH, Wildemann B, Back DA. Local application of zoledronic acid incorporated in a poly(D, L-lactide)-coated implant accelerates fracture healing in rats. Acta Orthop 2008;79:717-725.

29. Agholme $F$, Aspenberg P. Experimental results of combining bisphosphonates with allograft in a rat model. J Bone Joint Surg $\mathrm{Br}$ 2009;915:670-675.

30. Özer T, Akta A, Barı E, Çelik HH, Vatansever A. Effects of local alendronate administration on bone defect healing. Histomorphometric and radiological evaluation in a rabbit model. Acta Cir Bras 2017;32:781- 
795.

31. Nobre MDP, Fernandes RG, Chin CM, Faig-LH. Local action of sodium alendronate in bone repair of spontaneously hypertensive rat (SHR). Arq Bras Cardiol 2008;90:261-268.

32. Fu $\amalg$, Tang $\Pi$, Hao $Y Q$, Dai KR. Long-term effects of alendronate on fracture healing and bone remodeling of femoral shaft in ovariectomized rats. Acta Pharmacol Sin 2013;34:387-392.

33. Meganck JA, Begun DL, McElderry JD, Swick A, Kozloff KM. Fracture healing with alendronate treatment in the Brtl/+ mouse model of osteogenesis imperfecta. Bone 2013;56:204-212.

34. Li YT, Cai HF, Zhang ZL. Timing of the initiation of bisphosphonates after surgery for fracture healing: a systematic review and meta-analysis of randomized controlled trials. Osteoporos Int 2015;26:431-441.

35. De Sarkar A, Singhvi N, Shetty JN, Ramakrishna T, Shetye O, Islam $M$, et al. The local effect of alendronate with intra-alveolar collagen sponges on post extraction alveolar ridge resorption: A clinical trial. J Maxillofac Oral Surg 2015;14:344-356.

36. Limirio PHJO, Rocha FS, Batista JD, Guimarães-Henriques JC, Melo $G B$, Dechichi $P$, et al. The effect of local delivery doxycycline and alendronate on bone repair. AAPS Pharm Sci Tech 2016; 17:872-877.

37. Feng $Y$, Zhou M, Zhang $\mathrm{Q}_{\text {, Liu }} \mathrm{H}, \mathrm{Xu}$ Y, Shu L, et al. Synergistic effects of high dietary calcium and exogenous parathyroid hormone in promoting osteoblastic bone formation in rats. Br J Nutr 2015;113:909922.

38. Yun JI, Wikesjo UM, Borke JL, Bisch FC, Lewis JE, Herold RW, et al. Effect of systemic parathyroid hormone (1-34) and a beta tricalcium phosphate biomaterial on local bone formation in a critical-size rat calvarial defect model. J Clin Periodontol 2010;37:419-426.

39. Yoshioka T, Okimoto $N$, Okamoto $K$, Sakai A. A comparative study of the effects of daily minodronate and weekly alendronate on upper gastrointestinal symptoms, bone resorption, and back pain in postmenopausal osteoporosis patients. J Bone Miner Metab 2013;31:153-160. 